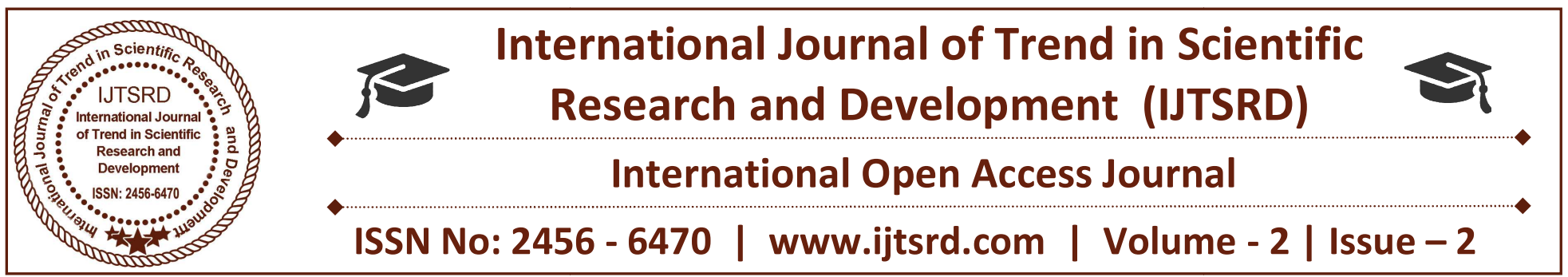

\title{
An Analysis and Study in Light of Phytoremediation of Heavy Metal Contaminated Soil
}

\author{
Narendra Kumar Bhatt \\ Research Scholar, Botany Department, \\ Mewar University, Rajasthan
}

\author{
Dr. H. N. Gour \\ Ex-Professor, Central Agricultural \\ University, Shilong, Meghalaya
}

\section{ABSTRACT}

The modern movement quickens contamination of the biosphere, particularly the soil. These days soil contamination is getting impressive open consideration since the size of this issue is developing quickly. Heavy metals are the most hazardous substances in the earth because of their abnormal state of toughness and harmfulness to the biota. Various examinations have been led around there went for building up an effective and prudent approach to remediate the soil contaminated with heavy metals. Regular remediation techniques, for example, physical, warm and concoction medications are exceptionally costly. Phytoremediation is a creating innovation which utilizes plants and their related organisms for the remediation of soil defilement. This procedure is practical without making unsettling influence to the scene. This paper resembles a point of reference or resource in distinguishing the issues related with heavy metal contaminated soil and other term known as Phytoremediation.

\section{Keywords: industry, soil, metal, plant,} Phytoremediation etc.

\section{Introduction:}

The world's regularly expanding populace and her dynamic selection of a mechanical based way of life has unavoidably prompted an expanded anthropogenic effect on the biosphere. In material generation openings exist for the discharge into the biological system of conceivably dangerous mixes at different phases of the operation. These poisons are deliver with an end goal to enhance human way of life and form yet incidentally, there spontaneous interruption into the earth can turn around a similar way of life by affecting adversely on the earth.

Gigantic volumes of gushing are produced at various phases of material assembling, because of the utilization duplicates measures of chemicals and colors. A few tons of materials required to get together with societal requests are created day by day in this industry. Effluents got from the material and dyestuff exercises can give genuine natural effect in the neighboring receptor bodies. The release of these waste deposits into the earth in the long run toxic substance, harm or influence at least one animal groups in nature, with resultant changes in the biological adjusts. Heavy metals will have a tendency to adsorb immovably to the soil framework, and once discharged to the earth, it won't debase like organics by microbial action or through compound oxidation. Human exercises, for example, mining, refining, electroplating, and so forth can bring about defilement of soil with heavy metals.

The present example of modern movement is modifying regular stream of material and bringing novel chemicals into nature. The rate at which effluents are released into the earth particularly water bodies is expanding because of urbanization. A large portion of these effluents contain poisonous substances particularly heavy metals. Heavy metals make a critical commitment to condition because of human exercises, for example, mining, refining, electroplating, vitality and fuel generation, control 
transmission, escalated horticulture, ooze dumping and liquefying operations. Some heavy metals e.g., $\mathrm{Mn}, \mathrm{Fe}, \mathrm{Cu}, \mathrm{Zn}, \mathrm{Mo}$ and $\mathrm{Ni}$ are basic as micronutrient for microorganisms, plants and creatures while others have no known natural capacity. Every single heavy metal at high fixations has solid lethal impacts and viewed as natural poisons.

\section{Review of literature:}

Davies (1997) contemplated heavy metal contaminated soil in an old mechanical zone of Wales, Great Britain. For this reason, they gathered 70 soil tests (up to $15 \mathrm{~cm}$ profundity) on a consistent lattice of $1000 \mathrm{~m}$ interim. These were removed utilizing $0.05 \mathrm{M}$ diammonium EDTA and the concentrates broke down for $\mathrm{Cd}, \mathrm{Co}, \mathrm{Cu}, \mathrm{Fe}, \mathrm{Mn}, \mathrm{Ni}$, $\mathrm{Pb}$ and $\mathrm{Zn}$. Factor investigation yielded three gatherings which clarified $73.8 \%$ of the information difference. It was inferred that factor three contained those components related with smelter outflows, factor one with tainting from the Lower Swansea Valley and in factor two pedogenetic forms control the event of the components.

Eko and Ibok (1998) reported the seasonal variation and partition of trace metals $(\mathrm{Fe}, \mathrm{Cu}, \mathrm{Mn}, \mathrm{Cd}, \mathrm{Cr}$ and $\mathrm{Pb}$ ) in surface sediments of Calabar River, south eastern Nigeria. They announced that concoction segment of the metals in the dregs uncovers that $30 \%$ of the aggregate metal load was contributed by the non-detrital (corrosive solvent) part, while finegrained have minerals/mixes are the principle bearers of the detrital (corrosive insoluble) portion.

Govil et al. (2001) did pollution of soil because of heavy metal in the Patancheru mechanical improvement zone, Andhra Pradesh, India. The primary target of the examination was to build up the spatial inconstancy in heavy-metal advancement and to evaluate the degree of defilement in the investigation zone. The information uncover that dirts in the region are fundamentally contaminated, demonstrating a few times more elevated amounts of poisonous components than typical. Numerous heavy metals, for example, $\mathrm{Cr}, \mathrm{V}, \mathrm{Fe}, \mathrm{As}, \mathrm{Cd}, \mathrm{Se}, \mathrm{Ba}, \mathrm{Zn}, \mathrm{Sr}$, $\mathrm{Mo}$ and $\mathrm{Cu}$, are available over the typical conveyance in the dirt. The heavy-metal heaps of the dirts in the examination region are $240 \mathrm{mg} / \mathrm{kg}$ for $\mathrm{Cr}, 235 \mathrm{mg} / \mathrm{kg}$ for $\mathrm{V}, 1,350 \mathrm{mg} / \mathrm{kg}$ for $\mathrm{Ba}, 200 \mathrm{mg} / \mathrm{kg}$ for $\mathrm{Cd}$, and 500 $\mathrm{mg} / \mathrm{kg}$ for $\mathrm{Cu}$.
Pandey et al. (2002) led observing of heavy metal collection in lichens from the Hetauda modern region Narayani zone Makwanpur District, Nepal and found the examples from the area inside the mechanical territory have more elevated amounts of metal than the outside territories. Pyxine meissnerina developing in inside the mechanical territory amassed more elevated amounts of all them metals broke down

Yilmaz et al. (2003) completed work on heavy metal fixations in surface soil of Izmit Gulf locale, Turcky. The tests were gone for examining the aggregate metal groupings of Cadmium, Cobalt, Chromium, Copper, Iron, Manganese, Nickel, Lead, and Zinc. From the aftereffects of investigation and correlations among soil composes, it is unmistakably demonstrated that urban and mechanical soils were contaminated more than country soils. Disc was not distinguished in any of the dirt examples. $\mathrm{Pb}$ improvement in urban and modern soils may be an aftereffect of fuel burning. The mean centralizations of $\mathrm{Co}, \mathrm{Cu}, \mathrm{Mn}, \mathrm{Pb}$, and $\mathrm{Zn}$ were found as $22,33,842$, 37 , and $72 \mathrm{mg} \mathrm{kg}-1$, individually.

Davis and Beckett (1978) detailed the basic centralization of heavy metals in the tissues of youthful grain plants and exhibited that an expansion in metal focus could cause poisonous quality and lessening in the yield of dry matter.Dhanraju (1987) additionally announced noteworthy abatement in biomass yield rate of Hibiscus sabdariffa because of an increment in metal level over the upper basic tissue grouping of heavy metals.

$\mathrm{Pb}, \mathrm{Cd}$, and $\mathrm{Zn}$ are ordinarily happening heavy metals and are consumed by plants regardless of their necessity. At the point when display at lifted levels, lessened development and impeded digestion can happen (Aery and Sarker, 1991)

Banu (1990) reported that at lower concentration of $\mathrm{Zn}, \mathrm{Pb}$, and $\mathrm{Cd}$ the phenolic contents of Hordeum vulgare and Brassica campestris plants decreased ,but the plants showed increased growth in term of dry matter. At higher concentrations of the above metals, an increase in the phenolic contents was observed. Hyperaccumulator plants can play a key role in the fate of the pollutants of contaminated matrixes via their root systems. Plants have been considered suitable for soil stabilization and extraction of heavy metals (Madejon et al. 2002). 
Gajanan S.Ghodake, et al. (2008) The Plant species (Brassica Juncea,Sorghum valgare and Phaseoles mungo ) of different consequence were evaluted for the decolorization of dyes from textile effluent . B.juncea,S.valgare \& P.mungo should. textile effeluent decolorization up to 79,57 and $53 \%$ Respectively. A significant decrese in shoot \& root height but no significant injury,was observed in the case of P.mungo ,S.valgare\&B.juncia (indian mustard) the most tolerant and more effective metals accumulator than other tested agricultural plant species.

Varsha Mudgal et.al.(2010) The plant used in the phytoremediation technique must have a considerable capacity of metal absorption. It's accumulation and strength to decrese the treatment time. Many families of vascular plants have been identified as metal hyperaccumulator (Reeves and Baker, 2000, Prasad and Feritas, 2003) and many of them belongs to Brassicaceae the hyperaccumulator are metal relative ,having slow growth rate,produce small amounts of biomass and can be used in their natural habits only.(Kamnav and Vander Lelic, 2000)

Akshya Pandey et.al.(2011) the amount of mercury present in the stem of a normal plant was found to be $0.219 \mathrm{ppm}$ and the amount of mercury present in the test plant was $0.327 \mathrm{ppm}$. the amount of mercury increase in the test stem attributes to the uptake of mercury by the lime plant with Brassicaceae nessed by th 'e upsurge in the value.

\section{Phytoremediation at a glance:}

The revelation of metal gathering properties in specific plants prompts the improvement of phytoremediation innovation. Research in the field of phytoremediation is intending to create imaginative, practical and earth perfect ways to deal with expel heavy metals from nature. Indeed, even separated from the metal hyper aggregating property of the plants, the nearness of ground cover with plants shields individuals from coordinate contact with the dirt and keeps the blowing of contaminated tidy around the area. Notwithstanding the phytoremediation, different points, for example, plant forms engaged with take-up, translocation, sequestration, and corruption of natural and inorganic toxins, and new improvements, for example, utilization of hereditary designing in the field of phytoremediation are likewise inspected. Sorts of Phytoremediation Technologies Phytoremediation can be characterizes as the joined utilization of plants, soil corrections and agronomic practices to expel toxins from the earth or to lessen its lethality. Contingent on the procedure by which plants are evacuating or diminishing the lethal impact of contaminants from the dirt, phytoremediation innovation can be comprehensively named takes after.

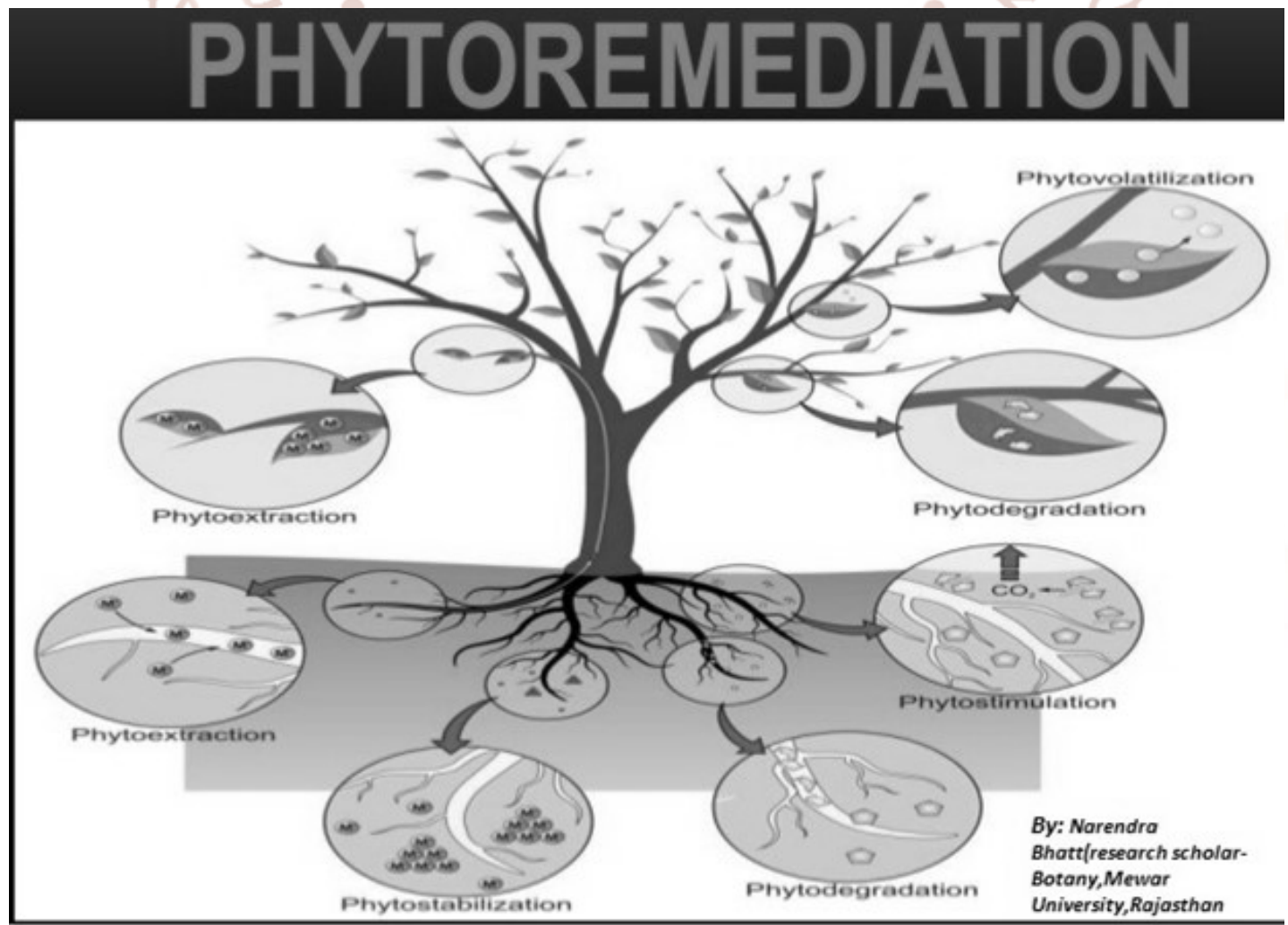

(Figure.1: Phytoremediation) 
3.1 Phytoextraction:This is the way toward utilizing toxin gathering plants to expel metals or organics from soil by moving them in harvestable plant parts.

3.2 Phytotransformation: This is the halfway or aggregate debasement of complex natural atoms by their joining into plant tissues.

3.3 Phytostimulation: In this procedure the arrival of plant exudates or proteins into the root zone empowers the microbial and parasitic corruption of natural poisons.

3.4 Phytostabilization: This is a strategy that utilizations plants to lessen portability of contaminants (both natural and metallic contaminants) by forestalling disintegration, filtering, or overflow and to diminish bioavailability of poisons in the earth, accordingly keeping their movement to groundwater or their entrance into the evolved way of life .

3.5 Phytovolatilisation: This is the technique of using plants to volatilize pollutants or metabolites.

\section{Sorts of Phytoremediation Technologies:}

Phytoremediation can be characterizes as the joined utilization of plants, soil revisions and agronomic practices to expel contaminations from the earth or to lessen its harmfulness. Contingent on the procedure by which plants are evacuating or diminishing the lethal impact of contaminants from the soil, phytoremediation innovation can be comprehensively delegated takes after.

4.1 Phytoextraction: This is the way toward utilizing toxin aggregating plants to expel metals or organics from soil by packing them in harvestable plant parts.

4.2 Phytotransformation: This is the fractional or aggregate corruption of complex natural particles by their fuse into plant tissues.

4.3 Phytostimulation: In this procedure the arrival of plant exudates or chemicals into the root zone invigorates the microbial and contagious debasement of natural toxins.
4.4 Phytostabilization: This is a technique that utilizations plants to diminish portability of contaminants (both natural and metallic contaminants) by anticipating disintegration, draining, or spillover and to decrease bioavailability of poisons in the earth, in this manner keeping their relocation to groundwater or their entrance into the evolved way of life.

4.5 Phytovolatilisation: This is the method of utilizing plants to volatilize toxins or metabolites. This innovation can be utilized for unstable natural carbons (VOCs) and for the few inorganics that can exist in unpredictable structures, for example, selenium and mercury .

4.6 Hydraulic control: It is the controlling of water table and soil field capacity by plant canopies.

\section{Phytoremediation of Heavy Metals in Soil :}

Heavy metal contamination of soil is still an unsolved problem. Heavy metal compounds in soil are very hazardous pollutants for the following reasons:
○ Non-biodegradable,
0 Extremely toxic at low concentrations, and
o Chances of mobilization under changing physical-chemical conditions.

Selection of a remediation technique for a site contaminated with metals is complex, time consuming and site specific. A few factors that impact choice of an appropriate methodology are size, area and history of site, openness to the site, viability of treatment alternatives, soil and contaminant qualities, accessibility of specialized and budgetary assets, and level of pollution. Phytoremediation is a rising innovation which can be adequately utilized for the remediation of metal contaminated destinations. The bioavailability of metals to plants is influenced by various factors, for example, soil and plant qualities, and different natural components. The principle soil qualities incorporate $\mathrm{pH}$, nearness of hydrous oxides of iron and manganese, natural issue content, dirt substance, phosphate content, redox potential, soil molecule estimate (surface territory of soil particles), and cation trade limit. Climatic conditions, water system, and soil preparing hones are cases of natural elements. The types of plant, character of plant tissue, and time of vegetation likewise influence metal takeup the metal take-up by a plant is relies upon the grouping of dissolvable and bioavailable division of 
metals in the soil arrangement. The bioavailable portion of metal in the soil can be controlled by the Potential Bioavailable Sequential Extraction (PBASE) technique Even however substance extraction won't extricate metal from the soil in a way indistinguishable to that of a plant root framework, it can be utilized as a dependable strategy for evaluating the bioavailability of metals bound to soil particles In a dirtied soil, the convergence of bioavailable toxins has a tendency to lessen after some time because of physical, compound and organic procedures.On account of this reason, matured soils are more hard to phytoremediate .It is realized that to upgrade metal dissolvability, plants either discharge natural ligands or lower the soil $\mathrm{pH}$ in the rhizosphere. To enhance metal dissolvability in the soil arrangement, engineered chelates, for example, ethylenediaminetetraacetic corrosive (EDTA), nitrilotriacetic corrosive (NTA), pyridine-2-6dicarboxylic corrosive (PDA), citrus extract, nitric corrosive, hydrochloric corrosive and fluorosilicic corrosive can be utilized as a part of phytoremediation ponders. The expansion of abundance chelating specialists may build the odds of filtering the metals from the soil to groundwater. On the off chance that the metal focus in the soil is close to the phytotoxic levels, at that point expansion of lime or natural issue decreases the metal dissolvability.

\section{Heavy Metal Toxicity to Plants:}

A noteworthy inconvenience of phytoremediation is that high centralizations of heavy metals or certain blends of heavy metals may antagonistically influences plant development and biomass creation by disturbing the physiology and morphology of plants. Some plant species can develop and create in metalliferous (metal rich soils) soils, for example, close to mining locales. Such plants can be used to tidy up heavy metal dirtied destinations. The general impacts of different metals in plant are :

6.1 Cadmium: Decreases seed germination, lipid content and plant growth, but induce the production of phytochelatins. Phytochelatin is a metal binding peptide and has an important role in cadmium detoxification in plants.

6.2 Chromium: Causes decrease in enzyme activity and plant growth, and produces membrane damage, chlorosis and root damage.

6.3 Copper: Disrupts photosynthesis, plant growth and reproductive processes, and decreases thylakoid surface area.
6.4 Mercury: Helps to accumulate phenol, but decreases the photosynthetic- activity, water uptake and antioxidant enzymes.

6.5 Nickel: Reduces seed germination, protein production, chlorophyll and enzyme production, and accumulation of dry mass, but increases the amount of free amino acids.

6.6 Lead: Reduces chlorophyll production and plant growth, but increases superoxide dismutase (metal containing antioxidant enzyme).

6.7 Zinc: Reduces nickel toxicity and seed germination, but increases plant growth and ATP/chlorophyll ratio at moderate concentrations.

\section{Conclusion:}

In this research paper we come to know about the heavy metals which adsorb immovably to the soil framework, and once discharged to the earth, it won't debase like organics by microbial action or through compound oxidation. Later we discussed about the Phytoremediation process which fundamentally alludes to the utilization of plants and related soil microorganisms to lessen the fixations or poisonous impacts of contaminants in the situations" It can be utilized for expulsion of overwhelming metals and radionuclides and also for natural contaminations.

Finally it can be easily assumed that this research paper is a great asset to understand the issues related with phytoremediation process, heavy metal toxicity etc.

\section{References:}

1. Alkorta I, Hernandez-Allica J, Becerril J. M, Amezaga I, Albizu I, Garbisu C: 2004, 'Recent findings on the phytoremediationof soils contaminated with environmentally toxic heavy metals and metalloids such as zinc, cadmium, lead, and arsenic', reviews in Environmental Science and Bio/Technology 3, 71-90.

2. Angelova V, Ivanov K, Ivanova R: 2004, Effects of chemical forms of $\mathrm{Pb}, \mathrm{Cd}$ and $\mathrm{Zn}$ in polluted soils on their uptake by Tobacco', Journal of Plant nutrition 27(5), 757-773.

3. Axtell N. R, Sternberg S. P. K, Claussen K: 2003, 'Lead and nickel removal using Microspora and Lemna minor', Bioresource technology 89, 41-48.

4. Basta N, Gradwohl R: 2000, 'Estimation of Cd, $\mathrm{Pb}$, and $\mathrm{Zn}$ bioavailability in smelter-contaminated soils by a sequential extraction procedure', journal of soil contamination 9(2), 149-164. 
5. Beiergrohslein Erik: 1998, 'The use of surfactants in removal of zinc, lead and cadmium from contaminated soils'.

6. Caille N, Swanwick S, Zhao F. J, McGrath S. P: 2004, 'Arsenic hyperaccumulation by Pteris ittatafrom arsenic contaminated soils and the effect of liming and phosphate fertilisation', nvironmental Pollution 132, 113-120.

7. Clemente R, Walker D. J, Bernal M. P: 2005, 'Uptake of heavy metals and As by Brassica juncea grown in a contaminated soil in Aznalcollar (Spain): The effect of soil amendments', Environmental pollution.
10. Garcia G, Faz A, Cunha M: 2004, 'Performance of Piptatherum miliaceum(Smilo grass) in edaphic $\mathrm{Pb}$ and $\mathrm{Zn}$ phytoremediation over a short growth period', International Bioremediation \& Biodegradation 54, 245-250.

11. Gardea-Torresdey J. L, Peralta-Videa J. R, de la Rosa G, Parsons J. G: 2005, 'Phytoremediation of heavy metals and study of the metal coordination by X-ray absorption spectroscopy', Coordination chemistry reviews.

12. Das J. (2003). Geochemistry of trace elements in the ground water of Cuttack city, India. Water, Air and Soil Pollution, 147, p.p. 129-140.
8. Ettler V, Vanek A, Mihaljevic M, Bezdicka P: 2005, 'Contrasting lead speciation in forest and tilled soils heavilypolluted by lead metallurgy', Chemosphere 58(10), 1449-1459.

9. Evanko C. R, Dzombak D. A: 1997, 'Remediation of metals - Contaminated soils and groundwater', Technology Evaluation report, Ground water remediation Technologies Analysis Center.
13. Davies B. E. (1997). Heavy metal contaminated soils in an old industrial area of Wales, Great Britain. Water, Air and Soil Pollution, 94, p.p. 85-98.

14. Aery,N.C. and Tiagi,Y.D.(1985), studies on the reclamation of tailing dam at Zawar Mines,Udaipur,India.

15. A.sharma : Phytoremedation : Anovel strategy for the ur clean -up of contaminated lands.(Ed.P.C.Trivedi) Avishker Publ, 